\title{
Regulation of steroidogenesis by insulin-like growth factors (IGFs) in adult human adrenocortical cells: IGF-I and, more potently, IGF-II preferentially enhance androgen biosynthesis through interaction with the IGF-I receptor and IGF-binding proteins
}

\author{
C Fottner, D Engelhardt and M M Weber \\ Laboratory of Endocrine Research, Medical Department II, Klinikum Grosshadern, University of Munich, Munich, Germany \\ (Requests for offprints should be addressed to M M Weber, Medizinische Klinik II, Klinikum Großhadern, Marchioninistraße 15, 81377 München, Germany)
}

\begin{abstract}
Although the effect of insulin-like growth factors (IGFs) in fetal adrenocortical cells has been investigated extensively, the role of the IGF system in the adult human adrenal gland remains unclear. In the present study we investigated the effect of recombinant human IGF-I and IGF-II on cortisol, dehydroepiandrosterone sulfate (DHEA-S) and cAMP synthesis in adult human adrenocortical cells in primary culture. Both IGFs stimulate basal as well as adrenocorticotropin (ACTH)-induced steroid secretion in a time- and dose-dependent fashion. While both IGFs $(6.5 \mathrm{nM})$ induced only a moderate 2 -fold increase in basal cortisol output after $48 \mathrm{~h}$, the effect on basal DHEA-S secretion was significantly stronger, with a $2 \cdot 7$ - and 3.7-fold stimulation by IGF-I and IGF-II respectively. Similarly, IGF-II enhanced ACTH-induced cortisol and DHEA-S secretion more potently than IGF-I. In doseresponse experiments, the maximum stimulation of ACTH-induced DHEA-S secretion was induced by 1.6 nM IGF-I (2-fold increase) or IGF-II (2.9-fold increase), while the maximum response of cortisol secretion was elicited only at $13 \mathrm{nM}$ IGF-I (2-fold increase) or IGF-II (2.5-fold increase). This resulted in a significant shift of the DHEA-S dose-response curves to the left, indicating a relative selective stimulation of androgen biosynthesis by physiologically low concentrations $(0 \cdot 4-3 \cdot 2 \mathrm{nM})$ of IGF-II, and less potently by IGF-I. At all doses tested, the steroidogenic effect of IGF-II was significantly stronger than the effect of IGF-I. Although both IGF receptors are
\end{abstract}

present in adult human adrenocortical cells, the steroidogenic effect of IGF-II is mediated through the IGF-I receptor, since $\left[\mathrm{Arg}^{54,55}\right] \mathrm{IGF}-\mathrm{II}$, which only binds to the IGF-I receptor, was equipotent with native IGF-II, whereas $\left[\mathrm{Leu}^{27}\right] \mathrm{IGF}-\mathrm{II}$, which preferentially binds to the type II IGF receptor, did not show any effect. In addition, [des ${ }^{1-3}$ ]IGF-I, which exhibits only minimal binding to IGFBPs, was significantly more potent than native IGF-I in stimulating adrenal steroid biosynthesis, and elicited almost the same maximum stimulatory effect as IGF-II and $\left[\mathrm{des}^{1-6}\right]$ IGF-II. By Western ligand blotting of conditioned medium it was shown that adult human adrenocortical cells secrete various IGF-binding proteins (IGFBPs), which are induced differentially by treatment with ACTH. In conclusion, these results demonstrate that: (1) IGF-II stimulates basal as well as ACTH-induced DHEA-S and cortisol secretion from adult human adrenocortical cells more potently than IGF-I; (2) both IGFs predominantly stimulate androgen biosynthesis; (3) the steroidogenic effect of IGF-I and IGF-II is mediated through interaction with the IGF-I receptor; (4) the different steroidogenic potency of IGF-I and IGF-II might be explained by interaction of these ligands with locally produced IGFBPs. These data indicate that the IGF system plays an important role in the regulation of the differentiated function of adult human adrenocortical cells. Journal of Endocrinology (1998) 158, 409-417

\section{Introduction}

The insulin-like growth factors IGF-I and IGF-II are involved in the regulation of cell growth and differentiation. While IGF-I mediates most of the somatotropic effects of growth hormone postnatally, IGF-II has been implicated as an important regulator of fetal growth. However, the role of IGF-II during postnatal life is less

clear. IGFs are synthesized in a highly regulated manner by a variety of tissues where they act at an autocrine/ paracrine level. Most growth- and differentiationpromoting effects of IGF-I and IGF-II are mediated by interaction of the ligands with the IGF-I receptor. The IGF-I receptor is a tyrosine kinase transmembrane receptor which binds IGF-I with high affinity and IGF-II only slightly less so. In contrast, the type II IGF receptor, which

Journal of Endocrinology (1998) 158, 409-417 (C) 1998 Society for Endocrinology Printed in Great Britain 0022-0795/98/0158-0409 \$08.00/0 
is identical with the cation-independent mannose-6phosphate receptor (IGF-II/M6P receptor), only binds IGF-II with high affinity and its role in IGF signaling remains unclear. In addition, the biological actions of IGFs are modulated by a family of at least six IGF-binding proteins (IGFBPs), which are synthesized locally by most tissues. Depending on the cellular context, IGFBPs are capable of inhibiting or enhancing IGF action and may even have ligand-independent effects (Humbel 1990, Nissley \& Lopaczynski 1991, Jones \& Clemmons 1995, Le Roith et al. 1995, Rajaram et al. 1997).

In comparison with other species, the human adrenal gland is unique in its large and developmentally regulated secretion of androgens such as dehydroepiandrosterone (DHEA), its sulfate (DHEA-S) and androstenedione. While serum levels of adrenocorticotropin (ACTH) and corticosteroids remain relatively constant during human development, DHEA and DHEA-S levels start to rise shortly before the onset of puberty (adrenarche), peak during young adulthood and decline progressively thereafter. Accumulating data indicate that the IGF system plays a role in the regulation of growth and differentiation of the adrenal gland (Penhoat et al. 1989, Reed \& James 1989, Weber et al. 1996). Previous studies have demonstrated the presence of IGF-I and IGF-II mRNA or peptides, both IGF receptors and various IGFBPs in the adrenal gland of several species, including humans (Pillion et al. 1988, Shigematsu et al. 1989, Townsend et al. 1990, Arafah 1991, Han et al. 1992, Weber et al. 1994, 1997). Furthermore, IGFs have been found to elicit mitogenic and differentiating effects on adrenocortical cells in vitro (Penhoat et al. 1989, Pham-Huu-Trung et al. 1991, Weber et al. 1995, 1996, Mesiano \& Jaffe 1997). In the fetal human adrenal gland, both IGFs stimulate cell proliferation, and IGF-II in combination with estrogen directs steroidogenesis toward androgen biosynthesis (Mesiano \& Jaffe 1997). It is assumed that IGF-II mediates ACTH-induced fetal adrenal growth, since ACTH induces IGF-II gene expression in adrenocortical cells, and IGF-II is expressed at a higher level than IGF-I in the fetal adrenal gland (Voutilainen \& Miller 1987, Ilvesmäki et al. 1992). The function and structure of the adult adrenal gland differ significantly from those of the fetal adrenal gland, and the role of the IGF system in adult human adrenocortical cells remains unclear. Adult human adrenal glands express IGF-I, to a lesser extent IGF-II, and both types of IGF receptor. Increased levels of IGF-II mRNA are found in adrenocortical carcinomas (Voutilainen \& Miller 1987, Ilvesmäki et al. 1993, Gicquel et al. 1994). However, scant information is available on the effect of IGFs in adult human adrenocortical cells (Pham-Huu-Trung et al. 1991, Kristiansen et al. 1997), and the role of the IGF-II receptors in IGF-II signaling in the adult human adrenal gland remains unclear (L'Allemand et al. 1996).

In order to clarify further the significance of the IGF system in the adult adrenal gland, we examined the effect of IGF-I and IGF-II on basal as well as ACTH-induced cortisol, DHEA-S and cAMP secretion from adult human adrenocortical cells in primary culture. In the present study, we demonstrate that, in adult human adrenocortical cells, both IGFs stimulate DHEA-S secretion more potently than cortisol secretion, and that the steroidogenic effect of IGF-II is stronger than that of IGF-I. By incubation experiments with mutant IGF ligands, we show that the effect of IGF-II is mediated through interaction with the IGF-I receptor and that the different potencies of IGF-I and IGF-II may be due to interaction of the ligands with IGFBPs.

\section{Materials and Methods}

\section{Materials}

Recombinant human IGF-I and IGF-II were purchased from Boehringer (Mannheim, Germany), mutant recombinant $\left[\right.$ des $\left.^{1-3}\right]$ IGF-I and $\left[\right.$ des $\left.^{1-6}\right]$ IGF-II were obtained from GroPep (Adelaide, Australia). The mutant recombinant human IGF-II analogs [Leu $\left.{ }^{27}\right]$ IGF-II and $\left[\operatorname{Arg}^{54,55}\right]$ IGF-II were kindly provided by Daiichi Pharmaceutical Co. (Tokyo, Japan). ACTH(1-24) (Synacthen) was purchased from Ciba-Geigy (Basel, Switzerland). ${ }^{125}$ I-cortisol was purchased from Sorin Biomedica AG (Braunschweig, Germany).

\section{Cell preparation and culture conditions}

Tissue from normal adult human adrenal glands was obtained from patients who had undergone total unilateral nephrectomy because of renal carcinoma, according to the guidelines of the local ethical committee. Immediately after surgical removal, the tissue was dissected by the pathologist and a sample of fresh non-necrotic adrenal tissue was provided. All adrenal glands used were found to be normal after morphological and histopathological examination. Monolayer cell cultures of adult human adrenocortical cells were prepared as described (Weber et al. 1995, Weber \& Michl 1996). In brief, adrenocortical tissue was separated, enzymatically dispersed with $1 \%$ collagenase II and $0 \cdot 25 \%$ DNase I $\left(30 \mathrm{~min}\right.$ at $\left.37^{\circ} \mathrm{C}\right)$, filtered $(100 \mu \mathrm{m})$ and centrifuged $(5 \mathrm{~min}$ at $400 \mathrm{~g})$. Red blood cells and cell debris were removed by washing with PBS followed by Percoll centrifugation $(\rho=1.07 \mathrm{~g} / \mathrm{ml}$, $37^{\circ} \mathrm{C}$; Pharmacia, Uppsala, Sweden) for $10 \mathrm{~min}$ at $730 \mathrm{~g}$. The band containing adrenocortical cells was washed twice with PBS, and resuspended in cell culture medium (M199; Gibco-BRL, Eggenstein, Germany) containing $10 \%$ fetal calf serum, $5 \%$ horse serum, L-glutamine $(290 \mu \mathrm{g} / \mathrm{ml})$, gentamicin $(50 \mu \mathrm{g} / \mathrm{ml})$ and amphotericin B $(0.5 \mu \mathrm{g} / \mathrm{ml}))$. Adrenocortical cells were then grown in monolayers at $37{ }^{\circ} \mathrm{C}$ in a humidified atmosphere with $95 \%$ air $/ 5 \% \mathrm{CO}_{2}$ for $3-4$ days in $22 \mathrm{~mm}$ multiwell plates. At 
$24 \mathrm{~h}$ before the experiments the medium was exchanged for serum-free medium (M 199 containing L-glutamine $(292 \mu \mathrm{g} / \mathrm{ml})$, gentamicin $(52 \mu \mathrm{g} / \mathrm{ml})$ and amphotericin B $(0.5 \mu \mathrm{g} / \mathrm{ml}))$. Treatment of the cells with ACTH under serum-free conditions induced a dose-dependent increase in cortisol secretion, with a half-maximal stimulation at $10^{-8} \mathrm{M}$ ACTH. At confluency, cell density was $(3-5) \times 10^{5}$ cells/well and cell viability was $>95 \%$ as confirmed by trypan blue exclusion after $96 \mathrm{~h}$ of incubation.

\section{Stimulation experiments and RIAs}

Adult human adrenocortical cells $\left((3-5) \times 10^{5}\right.$ cells/well $)$ were incubated with $1 \mathrm{ml}$ serum-free medium with or without ACTH $\left(10^{-8} \mathrm{M}\right)$ and IGFs at the indicated concentrations for up to $72 \mathrm{~h}$. At the time points indicated, medium was aspirated and stored at $-30{ }^{\circ} \mathrm{C}$ for further analysis. At the end of each experiment, cells were counted with a Coulter counter. Cortisol secreted into the medium was determined by a specific RIA as previously described (Weber et al. 1996). DHEA-S, IGF-I and IGF-II secretion into the medium were measured by specific RIA kits from Diagnostic Systems Laboratories (Active DHEA-S no. 3500, Active IGF-I no. 9100 and Active IGF-II no.5600) (Webster, Texas, USA), and the amount of cAMP in the medium was measured by the cAMP $\left[{ }^{125} \mathrm{I}\right]$ assay system from Amersham-Buchler (Braunschweig, Germany) as previously described (Weber et al. 1996). All assays have been validated for use in tissue culture medium, and their intra- and inter-assay coefficients of variation were less than $10 \%$. Assays were performed in duplicate and all experiments were repeated independently at least five times with a minimum of six independent wells per treatment group within each experiment.

\section{Western ligand blotting}

Human adrenocortical cells were incubated for $48 \mathrm{~h}$ with or without ACTH $\left(10^{-8} \mathrm{M}\right)$ under serum-free conditions. The medium corresponding to $5 \times 10^{5}$ cells was harvested, and IGFBPs were characterized in the conditioned medium from stimulation experiments by Western ligand blot as previously described (Weber et al. 1995). In brief, $1 \mathrm{ml}$ medium was concentrated tenfold, and $50 \mu \mathrm{l}$ of the sample were separated by SDS-PAGE $(12 \%$ gel) under non-reducing conditions in a Laemmli buffer system. Proteins were electrotransblotted on to polyvinylidene difluoride (PVDF) membranes (Immobilon; Millipore, Munich, Germany). The IGFBPs were identified by autoradiography after overnight incubation of the filters with ${ }^{125} \mathrm{I}$-labeled IGF-II at $4{ }^{\circ} \mathrm{C}$.

\section{Statistics}

All data are expressed as mean \pm S.E.M., and analysed by one-way ANOVA. Duncan's multiple range test was used

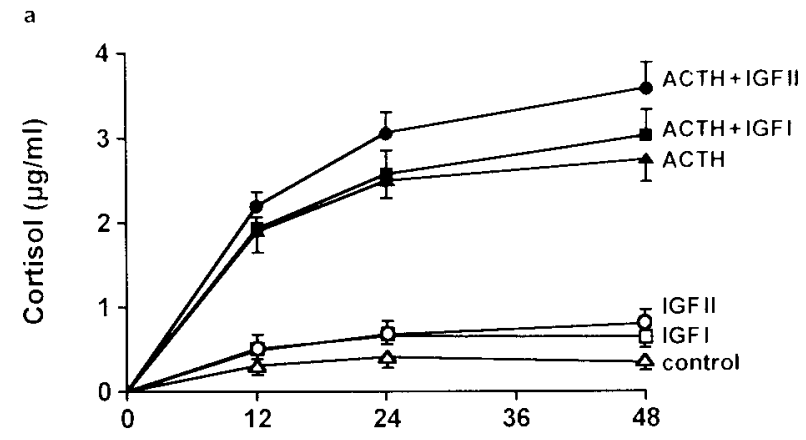

b

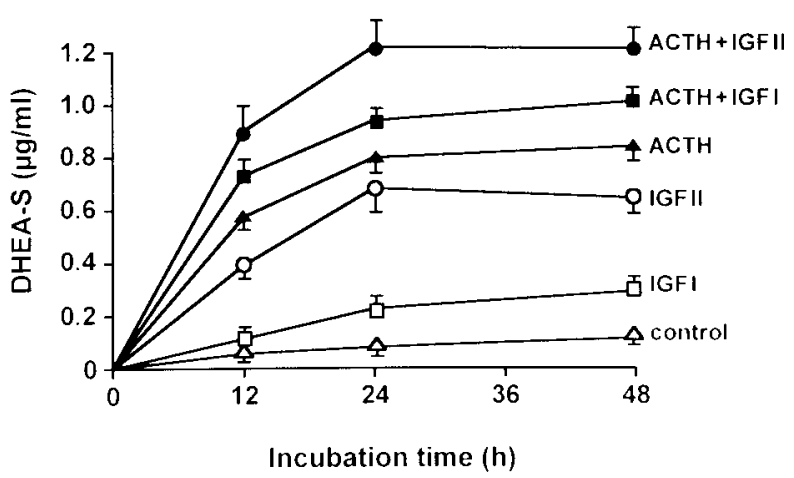

Figure 1 Time course of IGF action on basal and ACTH-stimulated cortisol (a) and DHEA-S (b) secretion in primary adult human adrenocortical cells. Cells $\left(5 \times 10^{5}\right)$ were incubated in multiwell plates for $48 \mathrm{~h}$ in the presence of ACTH $\left(10^{-8} \mathrm{M}\right)$, IGF-I $(6.5 \mathrm{nM})$ or IGF-II $(6.5 \mathrm{nM})$. At each time point, medium was aspirated and assayed for cortisol and DHEA-S. Each point represents results for six wells (mean \pm S.E.M.). Data are representative of a single experiment performed independently five times.

after ANOVA to compare significant differences between mean values. $P<0 \cdot 05$ was considered to be significant.

\section{Results}

IGF action on steroidogenesis in adult human adrenocortical cells

The mean baseline steroid secretion from $4 \times 10^{5}$ adult human adrenocortical cells after $48 \mathrm{~h}$ of primary culture was $0.34 \pm 0 \cdot 05 \mu \mathrm{g}$ cortisol and $0 \cdot 1 \pm 0 \cdot 01 \mu \mathrm{g}$ DHEA-S ( $n=10$ independently performed incubation experiments). When cells were treated with IGF-I or IGF-II, both ligands stimulated basal as well as ACTH-induced cortisol and DHEA-S secretion in a time-dependent fashion (Fig. 1). As expected, mean basal cortisol secretion was increased $8 \cdot 8 \pm 0 \cdot 9$-fold, and DHEA-S secretion $5 \cdot 0 \pm 1 \cdot 0$-fold by the addition of ACTH $\left(10^{-8} \mathrm{M}\right)$ for $48 \mathrm{~h}$. 
When the cells were treated with IGF-II $(6.5 \mathrm{nM})$ a moderate 2-fold increase in basal cortisol secretion was induced which was significant only after $48 \mathrm{~h}(P<0 \cdot 05)$, whereas the effect of IGF-I on cortisol biosynthesis did not reach significance. In contrast with the cortisol secretion, the stimulatory effect of IGF-II and IGF-I on basal DHEA-S secretion was markedly stronger and had already reached significance for both ligands after $24 \mathrm{~h}(P<0 \cdot 05)$. The stimulatory effect of IGF-II on basal DHEA-S secretion was stronger than the effect of IGF-I at all time points tested $(P<0 \cdot 05)$, and IGF-II stimulated DHEAS-S to almost the same extent as ACTH $(2 \cdot 7 \pm 0.5-$ and $3 \cdot 7 \pm 1 \cdot 0$-fold stimulation after $48 \mathrm{~h}$ by IGF-I and IGF-II respectively).

In the presence of ACTH, a further increase in cortisol secretion was induced by IGF-I $(9 \cdot 3 \pm 0 \cdot 5$-fold stimulation after $48 \mathrm{~h}$ ), and more potently by IGF-II $(14 \cdot 8 \pm 0 \cdot 6$-fold stimulation). While IGF-II significantly enhanced ACTH-induced cortisol secretion after $24 \mathrm{~h}$ $(P<0 \cdot 05)$, the potentiating effect of IGF-I on ACTHinduced cortisol secretion did not reach significance. Similarly, IGF-II stimulated ACTH-induced DHEA-S secretion more potently than IGF-I, with a $8 \cdot 2 \pm 1 \cdot 2$ - and a $9 \cdot 8 \pm 2 \cdot 1$-fold stimulation after $48 \mathrm{~h}$ by IGF-I and IGF-II $(6.5 \mathrm{nM})$ respectively. The potentiating effect of IGF-II on ACTH-induced DHEA-S secretion was significant after $12 \mathrm{~h}$ and had already reached its maximum after $24 \mathrm{~h}$. IGF-I significantly enhanced ACTH-induced DHEA-S secretion after $48 \mathrm{~h}(P<0 \cdot 05)$. As for the cortisol secretion, the effect of IGF-II on the DHEA-S secretion was significantly stronger than the effect of IGF-I $(P<0 \cdot 05)$. The stronger induction of DHEA-S secretion by IGFs was reflected by an increase in the molar DHEA-S/cortisol ratio. The DHEA-S/cortisol ratio of the untreated control group (0.9) was increased to 1.6 by IGF-I and to 2 by IGF-II. In contrast, treatment of the cells with ACTH decreased the DHEA-S/cortisol ratio to $0 \cdot 4$, and, in combination with IGFs, it was still decreased slightly to $0 \cdot 7$ and $0 \cdot 8$. No mitogenic effect of either ligand was observed under the cell culture conditions used.

The predominant effect of IGFs on androgen biosynthesis was confirmed in dose-response experiments (Fig. 2). Both IGFs stimulated ACTH-induced cortisol as well as DHEA-S secretion in a dose-dependent manner. In contrast with the ACTH-induced cortisol secretion, which was stimulated maximally by $13 \mathrm{nM}$ IGF-I (2-fold) or IGF-II (2.5-fold), ACTH-induced DHEA-S production was already maximally stimulated by $1.6 \mathrm{nM}$ IGF-I (2-fold) or IGF-II (2.9-fold). This resulted in a shift of the DHEA-S dose-response curves to the left, indicating selective stimulation of androgen biosynthesis by low concentrations $(0 \cdot 4-3 \cdot 2 \mathrm{nM})$ of IGF-I and, more potently, of IGF-II. The bell-shaped form of the dose-response curves, with a decrease in steroid output at very high concentrations of IGFs, was found consistently in all dose-response experiments and is probably due to inhi- a

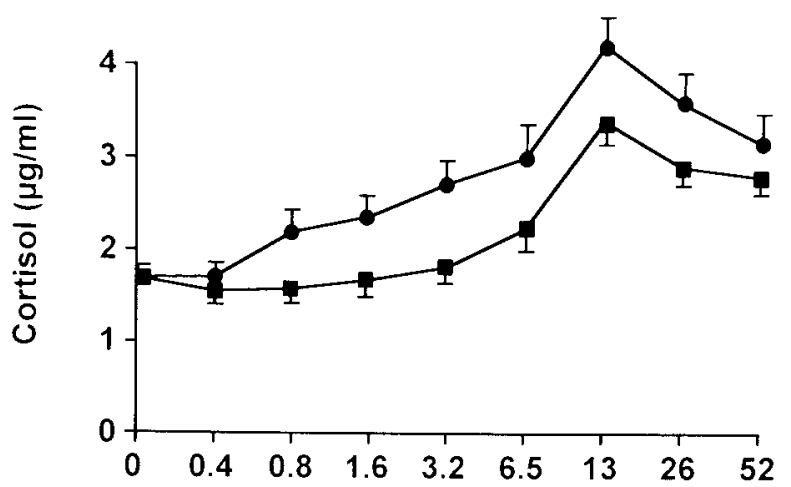

b

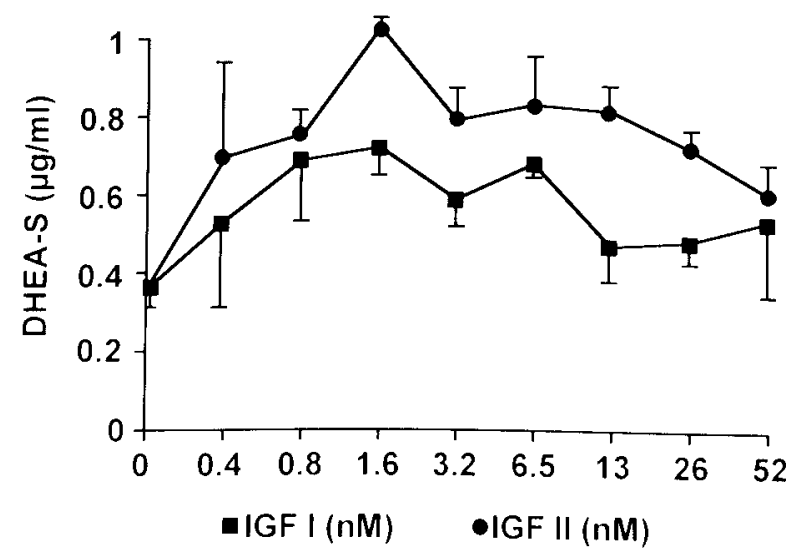

Figure 2 Dose-response curves of the action of IGFs on ACTH-induced cortisol (a) and DHEA-S (b) secretion in primary adult human adrenocortical cells. Cells $\left(3.5 \times 10^{5}\right)$ were incubated in multiwell plates in the presence of ACTH $\left(10^{-8} \mathrm{M}\right)$ and the indicated concentrations of IGF-I ( $\mathbf{\square})$ or IGF-II (-). After incubation for $36 \mathrm{~h}$, medium was aspirated and assayed for cortisol and DHEA-S. Results are the mean \pm S.E.M. for at least three independently performed experiments.

bition of key steroidogenic enzymes by pseudosubstrate effects (Hornsby \& Aldern 1984, Weber \& Michl 1996). Again, IGF-II was more potent than IGF-I in stimulating both ACTH-induced corticosteroid and androgen biosynthesis. This effect was most prominent at low concentrations, at which IGF-I did not show any significant effect on DHEA-S $(0.4 \mathrm{nM})$ or cortisol $(3.2 \mathrm{nM})$ secretion, whereas IGF-II already caused half-maximal stimulation $(P<0 \cdot 05)$. To exclude the possibility that the IGF doseresponse curves are constructed on top of a high basal IGF output, basal and ACTH-induced IGF secretion were assessed. The mean concentration of IGF-I and IGF-II in conditioned medium from $5 \times 10^{5}$ adult human adrenocortical cells after $48 \mathrm{~h}$ of primary culture was $0 \cdot 61 \pm 0 \cdot 3$ and $0 \cdot 81 \pm 0 \cdot 3 \mathrm{ng} / \mathrm{ml}$ respectively, and ACTH $\left(10^{-8} \mathrm{M}\right)$ treatment did not result in any significant change in IGF 


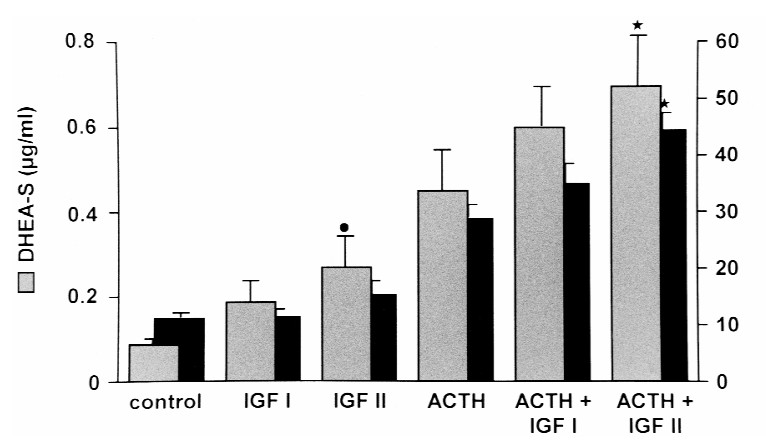

Figure 3 Effect of ACTH and IGFs on CAMP and DHEA-S production in primary human adult adrenocortical cells. Cells $\left(3.5 \times 10^{5}\right)$ were incubated in multiwell plates for $36 \mathrm{~h}$ in the presence of ACTH $\left(10^{-8} \mathrm{M}\right)$, IGF-I or IGF-II (6.5 nM). After incubation for $36 \mathrm{~h}$, medium was aspirated, pooled and assayed for DHEA-S (grey bars) and cAMP (black bars). Each bar represents the mean \pm S.E.M. for six independently performed experiments. $\bullet P<0.05$ vs untreated control group and IGF-I-treated group; ${ }^{*} P<0.05$ vs ACTH-treated group and ACTH+IGF-I-treated group.

levels $\quad(0 \cdot 6 \pm 0 \cdot 2 \mathrm{ng} / \mathrm{ml}$ IGF-I and $0 \cdot 54 \pm 0 \cdot 1 \mathrm{ng} / \mathrm{ml}$ IGF-II). Therefore the observed dose-response curves reflect truly effective IGF concentrations in the presence of low endogenous protein.

The stimulatory effect of IGFs on basal as well as ACTH-induced steroid secretion was paralleled by an increase in the accumulation of cAMP in the supernatant (Fig. 3). As expected, ACTH $\left(10^{-8} \mathrm{M}\right)$ was a potent stimulator of cAMP in the medium, with a $2 \cdot 6$-fold increase over control levels after an incubation period of $36 \mathrm{~h}$. Maximal levels of cAMP (3.9-fold of control) were achieved with a combination of ACTH and IGF II $(6.5 \mathrm{nM})$, while the combination of ACTH with IGF-I $(6.5 \mathrm{nM})$ was significantly less potent (3-fold stimulation, $P<0 \cdot 05)$. Treatment with IGF-I and IGF-II alone did not cause any significant increase in cAMP levels.

\section{Action of mutant IGF ligands on steroidogenesis}

To investigate the role of IGF receptors in mediating the steroidogenic effect of IGF-II in our cell culture system, mutant IGF-II ligands with altered affinities for both IGF receptors were utilized. [ $\left[\mathrm{Leu}^{27}\right]$ IGF-II, containing a leucine substitution for tyrosine at amino acid position 27, exhibits high affinity $\left(K_{\mathrm{d}} 0.05 \mathrm{nM}\right)$ for the type II IGF receptor, but only low affinity $\left(K_{\mathrm{d}} 66 \mathrm{nM}\right)$ for the type I IGF receptor. In contrast, [Arg ${ }^{54,55}$ ]IGF-II, containing an arginine substitution for alanine ${ }^{54}$ and leucine ${ }^{55}$, displays a high affinity $\left(K_{\mathrm{d}} 0 \cdot 4 \mathrm{nM}\right)$ for the IGF-I receptor and no binding to the IGF-II/M6P receptor (Sakano et al. 1991). $\left[\mathrm{Leu}^{27}\right]$ IGF-II $(6 \cdot 5 \mathrm{nM})$, which preferentially binds to the IGF-II/M6P receptor, failed to stimulate ACTH-induced cortisol secretion in adult human adrenocortical cells, despite the presence of abundant IGF-II/M6P receptors in

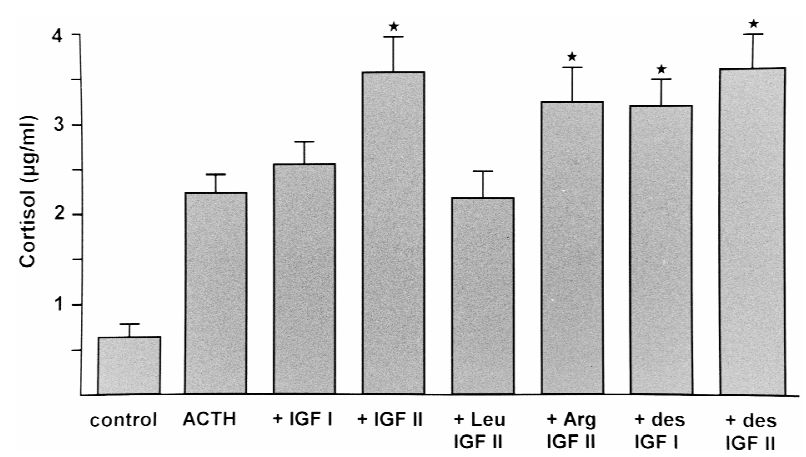

Figure 4 Effect of mutant IGF-II ligands with altered binding to IGF-receptors and IGFBPs on cortisol secretion in primary human adrenocortical cells. Cells $\left(5 \times 10^{5}\right)$ were incubated in multiwell plates in the presence of ACTH $\left(10^{-8} \mathrm{M}\right)$ and mutant or native IGF ligands (6.5 nM). After incubation for $48 \mathrm{~h}$, medium was aspirated and assayed for cortisol. Each bar represents the mean \pm S.E.M. for six independently performed experiments $\left({ }^{*} P<0 \cdot 05\right.$ vs ACTH treatment group $)$.

these cells (Weber et al. 1997). However, [Arg $\left.{ }^{54,55}\right]$ IGFII, which binds to the IGF-I receptor but not to the IGF-II/M6P receptor, stimulated cortisol secretion in human adult adrenocortical cells to the same extent as equimolar concentrations of native IGF-II (Fig. 4). This confirms that the effect of IGF-II on cortisol synthesis in human adrenocortical cells is mediated through interaction of the IGF ligands with the IGF-I receptor and not with the IGF-II/M6P receptor. Similar data were obtained when the effect of mutant ligands on DHEA-S secretion was investigated (data not shown).

To elucidate the modulatory role of IGFBPs in the bioactivity of IGF-I and IGF-II in our cell system, mutant IGF ligands with reduced affinities for IGFBPs were used (Fig. 4). $\left[\operatorname{des}^{1-3}\right]$ IGF-I and [des $\left.{ }^{1-6}\right]$ IGF-II are truncated IGF variants lacking the first three and six $\mathrm{N}$-terminal amino acids respectively. Both show substantially decreased binding to IGFBPs, while their affinities for the IGF receptors remain unaltered ([des $\left.{ }^{1-3}\right]$ IGF-I) or are slightly reduced (des[ $\left.{ }^{1-6}\right]$ IGF-II) (Francis et al. 1993). When ACTH-primed cells were treated with [des ${ }^{1-3}$ ]IGF-I $(6.5 \mathrm{nM})$ instead of native IGF-I, a significantly stronger stimulatory effect on ACTH-induced cortisol secretion was observed (1.9- vs $1 \cdot 4$-fold increase by $\left[\mathrm{des}^{1-3}\right]$ IGF-I and IGF-I respectively; $\left.P<0 \cdot 05\right)$. In contrast, [des ${ }^{1-6}$ ]IGF-II stimulated ACTH-induced cortisol secretion to the same extent as native IGF-II and $\left[\right.$ des $\left.^{1-3}\right]$ IGF-I. The fact that $\left[\right.$ des $\left.^{1-3}\right]$ IGF-I was equipotent with IGF-II points to a modulatory role for IGFBPs in the regulation of IGF-stimulated steroid secretion of adult human adrenocortical cells.

\section{Secretion of IGFBPs by adult human adrenocortical cells}

To confirm that adult human adrenocortical cells produce IGFBPs, the conditioned medium of $5 \times 10^{5}$ adult human 


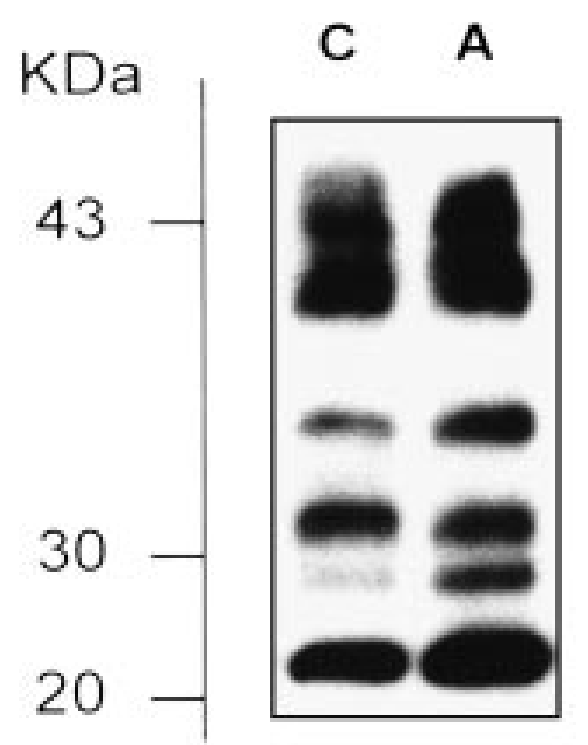

Figure 5 Western ligand blot of IGFBPs secreted by human adrenocortical cells. Cells $\left(5 \times 10^{5}\right)$ were incubated with serum-free medium alone (C) or ACTH $10^{-8} \mathrm{M}(\mathrm{A})$ for $48 \mathrm{~h}$. Conditioned medium was concentrated, separated by SDS-PAGE under non-reducing conditions, transfered to PVDF membranes, incubated with ${ }^{125}$ I-labeled IGF-II and autoradiographed. Data are representative of five independent experiments.

adrenocortical cells after $48 \mathrm{~h}$ of primary culture with and without ACTH stimulation was subjected to Western ligand blot analysis with ${ }^{125}$ I-IGF-II. As shown in Fig. 5, the medium of untreated control cells contains at least five specific bands, with a doublet of $39-44 \mathrm{kDa}$, and additional bands at 34, 31, 29 and $24 \mathrm{kDa}$. When the cells were treated with ACTH $\left(10^{-8} \mathrm{M}\right)$, the abundance of the various IGFBPs was induced differentially with preferential induction of the $29 \mathrm{kDa}$ band, and to a lesser extent of the $39-44 \mathrm{kDa}$ and $24 \mathrm{kDa}$ bands. According to their molecular masses, the $39-44 \mathrm{kDa}$ doublet presumably represents different glycosylation variants of IGFBP-3, the $34 \mathrm{kDa}$ band IGFBP-2, and the $24 \mathrm{kDa}$ band deglycosylated IGFBP-4. The size of the 29 and $31 \mathrm{kDa}$ bands, however, would be compatible with IGFBP-1, a fragment of IGFBP-3, glycosylated IGFBP-4, IGFBP-5 and IGFBP-6, and further investigations are required for their identification.

\section{Discussion}

Our data demonstrate that physiological concentrations of IGF-I and IGF-II stimulate basal as well as ACTHinduced cortisol and DHEA-S secretion in a time- and dose-dependent way. The effects of both IGFs were significant as early as after $24 \mathrm{~h}$, and were not due to growth-promoting effects, since the ligands did not elicit any changes in cell number under the conditions used.
Little is known about the mechanisms by which IGFs increase basal and ACTH-induced steroidogenesis in adrenal cells. In bovine adrenocortical cells, IGF-I upregulates $\mathrm{ACTH}$ receptors, while $\mathrm{ACTH}$ increases the abundance of IGF-I receptors and the secretion of IGFs (Penhoat et al. 1989, Reed \& James 1989, Pepe \& Albrecht 1990, Pham-Huu-Trung et al. 1991). In human adrenocortical cells, IGF-I induces synthesis of the mRNA of key steroidogenic enzymes and slightly increases ACTH receptor mRNA (L'Allemand et al. 1996, Kristiansen et al. 1997, Mesiano et al. 1997). To evaluate the mechanisms by which IGFs modulate adrenal steroidogenesis further, we measured cAMP in conditioned medium from adult human adrenocortical cells. The concentration of cAMP in the medium of intact adrenocortical cells reflects the intracellular action of adenylate cyclase caused by ACTH stimulation (Schimmer \& Schulz 1985). The fact that the stimulatory effect of IGF-I and IGF-II on ACTH-induced steroid secretion was paralleled by accumulation of cAMP in the medium supports the hypothesis that upregulation of ACTH receptors by IGFs is an important mechanism for the IGF-induced enhancement of the steroidogenic response of human adrenocortical cells to ACTH. However, the steroidogenic effects of IGF-I and IGF-II alone, which were not paralleled by an increase in cAMP levels, indicate that adult adrenocortical steroidogenesis is also regulated independently of cAMP by factors other than ACTH. This is supported by the study of Urban et al. (1994), who identified an IGF-responsive region in the porcine cholesterol side chain cleavage (P450 scc) gene, which mediates IGF-induced gene expression independently of but additively to the CAMP-induced stimulation. However, further investigations are needed to determine the signal-transduction pathway of IGF-induced adrenocortical steroidogenesis.

The steroidogenic effect of IGF-I in adult human adrenocortical cells reported in this study is consistent with previous reports of an IGF-I-stimulated steroidogenic response in bovine, ovine and human adrenocortical cells (Penhoat et al. 1989, Reed \& James 1989, Pepe \& Albrecht 1990, Pham-Huu-Trung et al. 1991, Weber et al. 1995, L'Allemand et al. 1996, Mesiano et al. 1997). However, little information is available on the effect of IGF-II in the adult human adrenal gland. In all incubation experiments performed, the steroidogenic effect of IGF-II on basal as well as ACTH-induced cortisol and DHEA-S secretion was significantly stronger than the effect of IGF-I. The difference in potency of IGF-I and IGF-II was most prominent at low concentrations, at which IGF-II already caused half-maximal stimulation of DHEA-S and cortisol secretion, whereas IGF-I did not yet show any effect. In accordance with our data, a stronger effect of IGF-II on ACTH-induced steroidogenesis was observed after preincubation of adult human adrenocortical cells for 3-4 days with very high concentrations (26 nM) of IGF-I and IGF-II (L'Allemand et al. 1996). In most cell systems, 
IGF-I and IGF-II transmit signals through the IGF-I receptor, and, according to their receptor affinities, the biological effects of IGF-I are usually stronger than those of IGF-II (Humbel 1990, Nissley \& Lopaczynski 1991, Weber et al. 1992, Le Roith et al. 1995). Since in adult human adrenocortical cells, which express abundant IGF-II/M6P receptors (Weber et al. 1997), IGF-II is more potent than IGF-I, it has been postulated that the effect of IGF-II could be mediated through the type 2 IGF receptor in these cells (L'Allemand et al. 1996). To evaluate further the differences between IGF-I and IGF-II in adult adrenocortical cells, we performed incubation experiments with mutant IGF ligands. The fact that $\left[\mathrm{Arg}^{54,55}\right]$ IGF-II, which does not bind to the IGF-II/M6P receptor but shows high affinity for the IGF-I receptor, was equipotent with native IGF-II, whereas [Leu $\left.{ }^{27}\right]$ IGF-II, which has a high affinity for the IGF-II receptor but exhibits only minimal binding to the IGF-I receptor, was ineffective in stimulating cortisol and DHEA-S secretion confirmed that the effect of IGF-II must be mediated through interaction with the IGF-I receptor, and that IGF-II/M6P receptors are not required for the stimulation of adult human adrenocortical steroid secretion by IGF-II.

In analogy with the human system, we have recently reported that IGF-II induces more potently than IGF-I, ACTH-stimulated cortisol secretion in adult bovine adrenocortical cells through interaction with the IGF-I receptor and IGFBPs (Weber 1995 et al.). As we have shown, adult human adrenocortical cells produce a variety of IGFBPs, which are induced differentially by treatment with ACTH. However, the physiological role of IGFBPs in the adrenocortical gland is unknown. Since IGFs are potent stimulators of adrenocortical cell function and IGFBPs are modulators of the cellular responsiveness to IGFs, changes in the cellular expression of IGFBPs may represent an important level of control in adrenocortical cell physiology. The fact that in adult human adrenocortical cells, IGFBPs are differentially upregulated by treatment with ACTH may contribute to the complex mechanism of homeostasis and modulation of IGF action in the adrenal gland, and provides strong evidence for an important regulatory role for IGFBPs in the adult human adrenal gland. This is supported by our finding of an increased steroidogenic effect of truncated IGF variants with reduced affinity for IGFBPs. The fact that $\left[\right.$ des $\left.^{1-3}\right]$ IGF-I, which exhibits decreased binding to IGFBPs, was significantly stronger than native IGF-I in stimulating ACTH-induced cortisol and DHEA-S secretion indicates that the discrepant potency of IGF-I and IGF-II in our cell system might be explained by interaction of the ligands with locally produced IGFBPs. As the poor binding of $\left[\mathrm{des}^{1-3}\right]$ IGF-I to IGFBPs correlates well with its increased bioactivity, a preferential interaction of IGF-I with an inhibitory IGFBP would be sufficient to explain the different stimulatory potency of IGF-I and IGF-II in human adrenocortical cells. This mechanism has been postulated for various other cell systems, where increased bioactivities of [ $\operatorname{des}^{1-3}$ ]IGF-I in comparison with native IGF-I have been found (Francis et al. 1993, Rechler 1995). However, IGFBPs are able to modulate IGF action through a variety of mechanisms (Rechler 1995, Rajaram et al. 1997), and our results do not show through which binding protein and what mechanism the modulatory effect of IGFBPs in our cell system is exerted. Since IGF-II has a higher affinity for most IGFBPs, it would be equally valid to discuss preferential enhancement of adrenocortical steroidogenesis by IGF-II, possibly via non-receptormediated mechanisms, as has been shown by Conover et al. (1994) in human fibroblasts. In this cell culture system, IGF-II induces proteolysis of the inhibitory IGFBP-4 more potently than IGF-I, thereby enhancing the mitogenic actions of IGF-I. This indicates the possibility that a similar IGFBP protease-dependent mechanism might be responsible for the enhanced steroidogenic effect of IGF-II in adult adrenocortical cells (Reed \& James 1989, Cara 1994). The fact that the stronger steroidogenic potency of IGF-II is conserved between the bovine and human adrenocortical cell culture system adds further support to the hypothesis that IGF-II is an important regulator of adrenocortical cell function, not only in the fetal but also in the adult adrenal gland. However, the physiological significance of IGF-II in the adult adrenal gland remains uncertain. A predominant role for IGF-II in the autocrine/paracrine regulation of adrenal steroidogenesis has been postulated from the coordinated expression of IGF-II and steroidogenic enzyme mRNAs in fetal human and ovine adrenal glands (Voutilainen \& Miller 1987, Han et al. 1992). In the adult adrenal gland, the abundance of IGF-II mRNA is very low. However, elevated levels of IGF-II mRNA/peptide are found in hormonally active adrenocortical carcinomas (Voutilainen \& Miller 1987, Ilvesmäki et al. 1993, Gicquel et al. 1994), and normal human adrenocortical cells secrete immunoassayable amounts of IGF-I and IGF-II in primary culture. Furthermore, adult IGF-II serum levels are very high (700 $\mathrm{ng} / \mathrm{ml})$, and the biologically active fraction that is not bound to IGFBPs might be large enough to exert an endocrine effect in the adrenal gland (Humbel 1990). An endocrine effect of elevated levels of IGF-II on the adrenal gland has recently been suggested by the findings of Wolf et al. (1994), who reported an increased adrenal weight in transgenic mice that develop elevated serum levels of IGF-II postnatally (Wolf et al. 1994). Adult bovine and human adrenocortical cells therefore represent a useful model system to help us to investigate the complex interaction of two IGF ligands, two IGF receptors, six IGFBPs and at least as many IGFBP-specific proteases. The delineation of the complex interaction between the various components of the IGF system in this cell culture model could be of great importance for the understanding of how this family of growth factors takes part in the regulation of differentiated steroidogenic cell function. 
The mechanisms that differentially regulate adrenal androgen biosynthesis during human development are unknown. Although circulating ACTH is the major regulator of corticosteroid and androgen synthesis in the adrenal gland, it has become apparent that the control of adrenocortical cell function is also modulated at a local level by a variety of growth factors (Penhoat et al. 1989, Reed \& James 1989, Pepe \& Albrecht 1990, Parker 1991, Weber et al. 1996). In the present studies, we have shown that, in adult human adrenocortical cells, IGF-I and IGF-II direct steroid biosynthesis toward androgen biosynthesis. While both IGFs at $6.5 \mathrm{nM}$ induced only a 2 -fold increase in basal cortisol secretion, basal DHEA-S secretion was stimulated 3- to 4-fold in the same incubation experiments. The predominant effect of IGFs on androgen secretion was confirmed in dose-response experiments. In the presence of $\mathrm{ACTH}$, the secretion of both steroids was further enhanced maximally 2 -fold by IGF-I and almost 3-fold by IGF-II. However, the maximum response of DHEA-S secretion was induced by 8 -fold lower concentrations of IGFs than the maximum response in cortisol secretion ( 1.6 vs $13 \mathrm{nM})$, resulting in selective stimulation of androgen biosynthesis by low concentrations of IGFs $(0 \cdot 4-3 \cdot 2 \mathrm{nM})$. Similarly, IGF-II has been shown to increase androgen production in fetal zone cells by eliminating the decrease in DHEA-S secretion that occurs at higher ACTH concentrations (Mesiano et al. 1997), and long-term preincubation of adult adrenocortical cells with IGFs results in a stronger ACTH-induced secretion of androstenedione and DHEA-S as compared with cortisol (L'Allemand et al. 1996). The preferential induction of adrenocortical androgen secretion by IGFs is probably based on their predominant and direct stimulation of the 17 $\alpha$-hydroxylase/17,20-lyase (P450c17) expression, which is a key enzyme of androgen biosynthesis (L'Allemand et al. 1996, Mesiano et al. 1997, Kristiansen et al. 1997). Since the onset of adrenarche is characterized by a relative increase in $\mathrm{P} 450 \mathrm{c} 17$ activity and coincides with an increase in IGF-I serum levels (Bala et al. 1981), it is tempting to speculate that the IGF system may be involved in the developmental regulation of adrenal androgen secretion. Furthermore, activation of the IGF-I receptor by IGFs or high levels of circulating insulin has been implicated in the pathogenesis of various states of hyperandrogenemia such as polycystic ovary syndrome (Barbieri et al. 1986). However, further studies are required to elucidate the role of the IGF system in regulating human adrenal cortical function.

In summary, our study demonstrates that IGF-I and IGF-II, through interaction with the IGF-I receptor, predominantly stimulate DHEA-S secretion in adult human adrenocortical cells, and that IGF-II is more potent than IGF-I in enhancing basal as well as ACTH-induced steroidogenesis. Furthermore, our results show that interaction of IGFBPs with IGF ligands may be responsible for the stronger steroidogenic potency of IGF-II in this cell model. These findings strengthen the hypothesis that the IGF system represents an important level of control in adrenocortical cell physiology.

\section{Acknowledgements}

The authors are grateful to Dr Sakano (Daiichi Pharmaceutical Co.) for kindly providing mutant IGF-II ligands, and to Gerald Spöttl and Barbara Adelmann for excellent technical assistance. The work was supported by DFG Grant WE 1356/4-1 (to M M W).

Teile dieser Arbeit enstanden im Rahmen der Dissertation von Herrn Christian Fottner an der Medizinischen Fakultät der Ludwig-Maximilians-Universität München, in Vorbereitung.

\section{References}

Arafah BM 1991 Insulin-like growth factor-I receptors in the rat adrenal. Journal of Laboratory and Clinical Medicine 118 531-537.

Bala RM, Lopatka J, Leung A, McCoy E \& McArthur RG 1981 Serum immunoreactive somatomedin levels in normal adults, pregnant women at term, children at various ages, and children with constitutionally delayed growth. Journal of Clinical Endocrinology and Metabolism 52 508-512.

Barbieri RL, Makris A, Randall RW, Daniels G, Kistner RW \& Ryan KJ 1986 Insulin stimulates androgen accumulation in incubations of ovarian stroma obtained from women with hyperandrogenism. Journal of Clinical Endocrinology and Metabolism 62 904-910.

Cara JF 1994 Insulin-like growth factors, insulin-like growth factor binding proteins and ovarian androgen production. Hormone Research 42 49-54.

Conover CA, Clarkson JT \& Bale LK 1994 Insulin-like growth factor-II enhancement of human fibroblast growth via a nonreceptor-mediated mechanism. Endocrinology 135 76-82.

Francis GL, Alpin SE, Milner SJ, McNeil KA, Ballard JF \& Wallace JC 1993 Insulin-like growth factor (IGF)-II binding to IGF-binding proteins and IGF receptors is modified by deletion of the N-terminal hexapeptide or substitution of arginine for glutamate-6 in IGF-II. Biochemical Journal 293 713-719.

Gicquel C, Bertagna X, Schneid H, Francillard-Leblond M, Luton JP, Girard F \& Le Bouc Y 1994 Rearrangements at the 11p15 locus and over expression of insulin-like growth factor-II gene in sporadic adrenocortical tumors. Journal of Clinical Endocrinology and Metabolism 78 1444-1453.

Han VKM, Lu F, Bassett N, Yang KP, Delhanty PJD \& Challis JRG 1992 Insulin-like growth factor-II (IGF-II) messenger ribonucleic acid is expressed in steroidogenic cells of the developing ovine adrenal gland: evidence of an autocrine/paracrine role for IGF-II. Endocrinology 131 3100-3109.

Hornsby PJ \& Aldern KA 1984 Steroidogenic enzyme activities in cultured human definitive zone adrenocortical cells: comparison with bovine adrenocortical cells and resultant differences in adrenal androgen synthesis. Journal of Clinical Endocrinology and Metabolism 58 121-127.

Humbel RE 1990 Insulin-like growth factors I and II. European Journal of Biochemistry 190 445-462.

Ilvesmäki V, Blum WF \& Voutilainen R 1992 Insulin-like growth factor-II in human fetal adrenals: regulation by ACTH, protein kinase C and growth factors. Journal of Endocrinology 137 533-542. 
Ilvesmäki V, Kahri AI, Miettinen PJ \& Voutilainen R 1993 Insulin-like growth factors (IGFs) and their receptors in adrenal tumors: high IGF-II expression in functional adrenocortical carcinomas. Journal of Clinical Endocrinology and Metabolism 77 $852-858$.

Jones JI \& Clemmons DR 1995 Insulin-like growth factors and their binding proteins: biological actions. Endocrine Reviews 16 3-34.

Kristiansen SB, Endoh A, Casson PR, Buster JE \& Hornsby PJ 1997 Induction of steroidogenic enzyme genes by insulin and IGF-I in cultured adult human adrenocortical cells. Steroids 62 258-265.

L'Allemand D, Penhoat A, Lebrethon M-C, Ardèvol R, Baehr V, Oelkers W \& Saez JM 1996 Insulin-like growth factors enhance steroidogenic enzyme and corticotropin receptor messenger ribonucleic acid levels and corticotropin steroidogenic responsiveness in cultured human adrenocortical cells. Journal of Clinical Endocrinology and Metabolism 81 3892-3897.

LeRoith D, Werner H, Beitner-Johnson D \& Roberts CT 1995 Molecular and cellular aspects of the insulin-like growth factor I receptor. Endocrine Reviews 16 143-163.

Mesiano S \& Jaffe RB 1997 Developemental and functional biology of the primate fetal adrenal cortex. Endocrine Reviews 18 378-403.

Mesiano S, Katz SL, Lee JY \& Jaffe RB 1997 Insulin-like growth factors augment steroid production and expression of steroidogenic enzymes in human fetal adrenal cortical cells: implications for adrenal androgen regulation. Journal of Clinical Endocrinology and Metabolism 82 1390-1396.

Nissley P \& Lopaczynski W 1991 Insulin-like growth factor receptors. Growth Factors 5 29-43.

Parker LN 1991 Control of adrenal androgen secretion. Endocrinology and Metabolism Clinics of North America 20 401-421.

Penhoat A, Jaillard C \& Saez JM 1989 Synergistic effects of corticotropin and insulin-like growth factor I on corticotropin receptors and corticotropin responsiveness in cultured bovine adrenocortical cells. Biochemical and Biophysical Research Communications 165 355-359.

Pepe GJ \& Albrecht ED 1990 Regulation of the primate fetal adrenal cortex. Endocrine Reviews 11 151-176.

Pham-Huu-Trung MT, Villette JM, Bogyo A, Duclos JM, Fiet J \& Binoux M 1991 Effects of insulin-like growth factor-I (IGF-I) on enzymatic activity in human adrenocortical cells. Interactions with ACTH. Journal of Steroid Biochemistry and Molecular Biology 39 903-909.

Pillion DJ, Yang M \& Grizzle WE 1988 Distribution of receptors for insulin-like growth factor-I (somatomedin C) in the adrenal gland. Biochemical and Biophysical Research Communications 154 138-145.

Rajaram S, Baylink DJ \& Mohan S 1997 Insulin-like growth factorbinding proteins in serum and other biological fluids: regulation and functions. Endocrine Reviews 18 801-831.

Rechler MM 1995 Non-receptor-binding proteins for insulin-like growth factors and other cytokines: modulators of peptide action. In Molecular Endocrinology. Basic Concepts and Clinical Correlations, vol 1, pp 155-180. Ed BD Weintraub. New York: Raven Press.

Reed MJ \& James VHT 1989 Regulation of steroid synthesis and metabolism by growth factors. Clinical Endocrinology 31 511-525.

Sakano K, Enjoh T, Numata F, Fujiwara H, Marumoto Y, Higashihashi N, Sato Y, Perdue JF \& Fujita-Yamaguchi Y 1991
The design, expression and characterization of human insulin-like growth factor II (IGF-II) mutants specific for either the IGF-II/ cation-independent mannose-6-phosphate receptor or IGF-I receptor. Journal of Biological Chemistry 266 20626-20635.

Schimmer BP \& Schulz P 1985 The roles of cAMP and cAMP-dependent protein kinase in forskolin's actions in $\mathrm{Y} 1$ adrenocortical tumor cells. Endocrine Research 11 199-209.

Shigematsu K, Niwa M, Kurihara M, Yamashita K, Kawai K \& Tsuchiyama H 1989 Receptor autoradiographic localization of insulin-like growth factor-I (IGF-I) binding sites in human fetal and adult adrenal glands. Life Sciences 45 383-389.

Townsend SF, Dallman MF \& Miller WL 1990 Rat insulin-like growth factor-I and-II mRNAs are unchanged during compensatory adrenal growth but decrease during ACTH-induced adrenal growth. Journal of Biological Chemistry 256 22117-22122.

Urban RJ, Shupnik MA \& Bodenburg YH 1994 Insulin-like growth factor-I increases expression of the porcine P-350 cholesterol side chain cleavage gene through a GC-rich domain. Journal of Biological Chemistry $26925761-25769$.

Voutilainen R \& Miller WL 1987 Coordinate tropic hormone regulation of mRNAs for insulin-like growth factor II and the cholesterol side-chain-cleavage enzyyme, P450 ssc, in human steroidogenic tissues. Proceedings of the National Academy of Sciences of the USA 84 1590-1594.

Weber MM \& Michl P 1996 Primary culture of bovine and human adult adrenocortical cells. In Endocrine Methods, vol 1, pp 393-416. Ed JA Thomas. San Diego: Academic Press.

Weber MM, Melmed S, Rosenbloom J, Yamasaki H \& Prager D 1992 Rat somatotroph insulin-like growth factor-II (IGF-II) signaling: role of the IGF-I receptor. Endocrinology 131 2147-2153.

Weber MM, Kiess W, Beikler T, Simmler P, Reichel M, Adelmann B, Kessler U \& Engelhardt D 1994 Identification and characterization of insulin-like growth factor I (IGF-I) and IGF-II/mannose-6-phosphate (IGF-II/M6P) receptors in bovine adrenal cells. European Journal of Endocrinology 130 265-270.

Weber MM, Simmler P, Fottner C \& Engelhardt D 1995 Insulin-like growth factor II (IGF-II) is more potent than IGF-I in stimulating cortisol secretion from cultured bovine adrenocortical cells: interaction with the IGF-I receptor and IGF-binding proteins. Endocrinology 136 3714-3720.

Weber MM, Fottner C, Auernhammer CJ, Spöttel G \& Engelhardt D 1996 Effect of IGF-I and IGF-II on steroidogenesis and IGFbinding protein synthesis in cultured human adrenocortical cells. 10th International Congress of Endocrinology, San Francisco, OR 56.

Weber MM, Auernhammer CJ, Kiess W \& Engelhardt D 1997 Insulin-like growth factor receptors in normal and tumorous adult human adrenocortical glands. European Journal of Endocrinology 136 296-303.

Wolf E, Kramer R, Blum WF, Föll J \& Brem G 1994 Consequences of postnatally elevated insulin-like growth factor-II in transgenic mice: endocrine changes and effects on body growth and organ growth. Endocrinology 135 1877-1886.

Received 21 January 1998

Accepted 22 April 1998 